The same year (1897) the micromotoscope was again described and illustrated in Photograms, a London periodical, which said: "During the year two distinct steps have been made in kinematography"; then, after giving a description of Dr. Macintyre's invention in radiography, the editor proceeded :

"Dr. Watkins, on the other hand, combined kinetography and photomicrography, so as to be able to record and reproduce the movements of objects so small as corpuscles, rotifers, microbes. This power of studying the motion of the corpuscles is expected to prove of infinite value in the diagnosis of certain diseases. From chis it will be seen that kinetography, which commenced as a scientific industry, has made distinct steps in scientific progress,
in addition to captivating the public taste. ."

Not only was credit given me in the periodicals quoted above, but the "Standard Dictionary," I905 edition, in defining the micromotoscope, refers to me as its inventor.

At about 1898, I again demonstrated this machine to a private audience at my house in the presence of Mr. Hopkins, editor of the Scientific American, Dr. G. L. Curtis, Dr. Fitch, Dr. J. H. Gunning, Mr. Robert Niles, and a few others of this city.

With the assistance of Mr. Thomas F. Livingston and Mr. E. W. Clausing, the micromotoscope was also shown at the Grand Central Palace of this city in the fall of 1897 at the Trained Nurses' and Pure Food Exhibition. Numerous microscopic objects, taken with the micromotoscope, were projected on the screen at this exhibition. Among others were the circulation of the blood in the web of the frog's foot, rotifers in stagnant Croton water, an ameboid leucocyte, moving bloodcells under the microscope, moving germs in fermenting urine, micrococei and bacteria, etc. Some of these positives were printed in the Edison Laboratory, East Orange, N. J.

At the time of this exhibition Dr. F. M. Jeffries of the New York Polyclinic furnished me with some specimens of typhoid germs, of which I made micromotoscope negatives. The above pictures were shown to over 10,000 people; one night these photographs were thrown right across the length of the immense main hall, producing a magnification of about $1,500,000$ diameters, according to our rough figures. Some of the microscopic objects looked like "whales and sea-serpents," as some in the audience observed. Charles L. Bristol, Professor of Biology in the New York University, remarked at the time that he had not supposed that this could be done.

Mr. F. M. Ramsden of Santiago, Cuba, who was very much interested in this scientific achievement, is in the possession of the only photograph I took of my first micromotoscope outfit in position ready to work. The first pictures that were taken by it were specially mounted for and presented to Dr. Abraham Jacobi, who now has them, and who readily remembered it, when I mentioned the fact to him a few days ago.

Since this first outfit, I have gradually improved my camera, making it more simple, until $I$ have at last produced the unique machine which I am now using. In experimenting on this micromotoscope, I have used up enough machinery and material to fill up a good-sized junk-shop.

The latest demonstration of the last pictures taken with this machine took place in Chicago on June 17 of this year, where I showed it to an audience of 500 doctors of the National Eclectic Association. Had I not been delayed with the construction of my new projecting machine, a demonstration of the micromotoscope would have taken place at the American Medical Association meeting in Atlantic City, last June.

I can cite many more instances to prove the validity of my claim of being the first to conceive this idea and demonstrate with a machine and photographs. The credit, then, for this invention rightly belongs to an American and not to a French: man.

Robert L. Watkins, M.D., New York.

\section{Free Use of the Mails for Literature on Public Health}

To the Editor:-About two years ago an effort was made by the state health officer of Florida to obtain for the various State and Territorial boards of health of the United States the privilege of free service through the mails for the distribution within State and Territory lines of sanitary and health bulletins and matters connected therewith. The measure was formulated into House Bill No. 11,317 and introduced by Hon. S. M. Sparkman, representative from the First Congressional District of Florida. When this measure was first proposed, the state health officer of Florida wrote to every State and Territorial board of health asking their cooperation through their representatives in Congress. Encouraging replies were received from all. It was hoped that the measure would become a law, especially since Mr. Sparkman received decided encouragement in his interview on the subject with the Postmaster-General. Later on, however, Mr. Sparkman was informed that President Roosevelt opposed the granting of this privilege; hence, of course, it was useless to proceed further with the measure.

The bill, as introduced, read as follows:

H. R. 11317 .

$$
\text { A BILL }
$$

To extend the franking privilege to literature published by boards of health of states, territories, and municipalities in the United States.

Be it enacted by the Senate and House of Representatives of the United States of America in Congress assembled :

That it shall be lawful to transmit through the mails, free of postage, any printed letters circulars, documents, pamphlets, and literature relating exclusively to the public health, which shall be issued by or under the authority of any board of health of any state, territory or city in the United States.

Sec. 2. That every such letter or package to entitle it to pass free shall bear over the words "Public Health Business" an indorsement showing the name of the state, territorial or municipal board of health, as the case may be, whence transmitted. And if any person shall make use of any such official envelope to avoid the payment of postage on his private letter, package or other mat ter in the mail, the person so offending shall be deemed gullty of a misdemeanor and subject to a fine of three hundred dollars, to be prosecuted in any court of competent jurisdiction.

Now, there seems to be no good reason why the United States mails should not be made a medium for disseminating useful and instructive sanitary information to the people. Measures taken to inform the general public on questions relating to their health and life seem as important as political dosuments - to the mind of every intelligent citizen even more so; certainly capable of favorable comparison with the instance reported in the public press of "the franking of a set of furniture through the mails by a representative in Congress from his home at Washington when near the completion of his term of office."

This matter is now submitted to the medical profession and the health officials of the United States with the hope that they may approve the measure, give it strong endorse. ment to congressional delegations from each state of the union, and urge it with all fervency as an appeal to benefit humanity and to increase the life tenure of the citizen. Joseph Y. Porter, Key West, Fla. State Health Officer of Florida.

\section{Ability, the Real Test}

To the Editor: There is a tendency on the part of the embryonic medical practitioner to become imbued with the foolish idea, after he has formally done with the state medical examining board, and procured a license to practice the healing art, that the public cares only to know that he has spent so many years in the high school, so many years in the academy, so many years in the college of liberal arts, so many years in the medical department of some university, and so much time as an intern.

The length of time spent in a college, or a dozen colleges, is no guarantee of knowledge acquired, nor is it a gage by which the public may reckon the fitness of a man to practice the principles of the craft. In fact, years have nothing to do with gaging the mental capacities of men. Men's mental abilities vary. Man's individual ability is as varied as his undertakings, and he achieves the really great things only after he has tried himself out. Therefore, there should be but one testthe test of ability, not the test of time as spaced off by college men. Nor is this statement intended to cast any reflections whatever on those who are engaged in the teaching of medicine.

Avoid the exaggeration, and remember this: the public cares little how long we have studied a particular subject, but rather how much we know of it!

Clyde A. Henry, M.D., Farson, Iowa. 